\title{
ANALISIS KONTRIBUSI GENDER DALAM BUDIDAYA TANAMAN KUCAI SKALA RUMAH TANGGA DI LAHAN PEKARANGAN
}

\author{
Lintar Brillian Pintakami \\ Dosen Program Studi Agribisnis, Fakultas Pertanian, Universitas Islam Balitar, Blitar \\ Email : lintarbrillianpintakami@unisbablitar.ac.id
}

\begin{abstract}
The purpose of this study was to describe the participation of women farmers in the formation of Kampung Kucai through Kelompok Wanita Tani (KWT), as well as identifying gender roles and assessing the extent of women's contribution to household income through home gardening optimization for farming activities in Kampung Kucai. the location of the research is purposive in Kampung Kucai, Dusun Kranggan, Pojok Village, Blitar Regency. The study was conducted from March to April 2018. The sampling method used in this study was snowball sampling. The number of respondents in the study were 20 respondents, both husband and wife who were actively involved in Kelompok Wanita Tani (KWT) in Kampung Kucai. In addition there are 5 Key Informants. Data analysis used descriptive analysis using qualitative and quantitative approach. Based on the data analysis it can be seen that the participation of women in the formation of the village of kucai in the form of cultivation of kucai, promoting, until the sustainable management. The identification of gender roles in the management of cucumber farming in the yard is analyzed by differentiating roles / activities, differences of control (power) and access (opportunities), and benefits between men and women. Then for the time allocation of men in the role of production shows greater than women. Men allocate production roles for 10 hours / day or 66.7\%. While women allocate production role for 5 hours / day or 33,3\%. So that each contribution in household net income each month is Rp. 460,230, - for men and Rp. 229.770, - for women. While the allocation of female reproductive role is bigger than men with value respectively $50 \%$ and $14,5 \%$.
\end{abstract}

Keyword: gender role, female farmer, work load, income contribution

\section{PENDAHULUAN}

Sebagai negara agraris, Indonesia memiliki masyarakat yang sebagian besar menggantungkan hidupnya di sektor pertanian. Menurut Kepala Badan Pusat Statistik seperti dikutip oleh Tempo (2017), sebanyak 39,68 juta orang atau 31,86 persen dari jumlah penduduk bekerja, berprofesi pada bidang pertanian. Tujuan pembangunan nasional melalui kebijakan yang diterapkan oleh pemerintah adalah dengan peningkatan taraf ekonomi masyarakat melalui pembangunan pertanian (Ningtyas, 2013). Badan Pusat Statistik mencatat laju pertumbuhan penduduk sebesar 1,36 persen dengan pertambahan penduduk \pm 30 juta jiwa dalam kurun 2010-2016 dan penurunan luas lahan 
sawah nasional sejak 2013 (BPS, 2017). Meningkatnya pertumbuhan populasi penduduk dan makin terbatasnya ketersediaan lahan dewasa ini menuntut pola pikir dan tindakan kreatif dalam upaya merancang praktek agribisnis yang inovatif. Demikian pula, dalam pembangunan pertanian diperlukan pendekatan inovasi agribisnis yang kreatif, mengingat pertanian adalah salah satu sektor strategis, terutama sebagai penyedia pangan, papan, sandang, dan energi bagi masyarakat (Rahayu dalam Marhalim, 2015).

Pemanfaatan lahan pekarangan menjadi salah satu pendekatan inovasi agribisnis yang srategis khususnya untuk ibu rumah tangga (Yulida, 2013). Bahkan, menurut Ashari (2012) pemanfaatan lahan pekarangan yang berada di sekitar rumah jika dikembangkan secara baik akan dapat bermanfaat lebih jauh lagi, seperti memberikan tambahan pendapatan ekonomi. Pada perspektif sebagian besar masyarakat, kaum perempuan "hanya" berperan sebagai istri dan ibu, dan dianggap tidak dapat memberikan kontribusi apapun dalam pendapatan (Handayani, 2009). Optimalisasi lahan pekarangan diharapkan dapat memberikan peluang bagi ibu rumah tangga untuk lebih memanfaatkan waktu senggang melalui usahatani pertanian sehingga mampu memberikan pendapatan tambahan rumah tangga (Ashari, 2012; Puspitasari, Puspitawati, dan Herawati, 2013; Yulida, 2013).

Rosmini (2007) menyatakan bahwa perempuan melalui perannya di rumah sebagai pribadi, istri, dan ibu rumah tangga juga memiliki andil penting sebagai penentu kebijakan bila kepadanya diberikan kesempatan penuh untuk berkreasi. Salah satu program pemerintah dalam memberikan peluang khususnya bagi perempuan untuk berkarya adalah dengan adanya pembentukan organisasi Kelompok Wanita Tani (KWT). Organisasi ini bertujuan untuk meningkatkan dan mengembangkan kemampuan petani dan keluarganya sebagai subjek pembangunan pertanian melalui pendekatan kelompok agar lebih berperan dalam pembangunan. Kelompok Wanita Tani Al-Afiah, An-Nisa, dan Manfaat adalah kelompok tani wanita yang aktif dalam mengembangkan partisipasi perempuan melalui pengoptimalan lahan pekarangan sekitar rumah. Beranggotakan para ibu rumah tangga, kelompok ini merintis terbentuknya Kampung Kucai di Dusun Kranggan, Desa Pojok, Kabupaten Blitar, sejak tahun 2013.

Kucai (Allium tuberosum) dipilih sebagai komoditi usahatani karena proses budidaya yang mudah, masa panen yang relatif cepat, tidak membutuhkan lahan luas, serta bentuk daun bawang kucai yang berukuran kecil menyerupai rumput teki dianggap dapat dijadikan sebagai tanaman hias sekitar pekarangan rumah, sehingga selain bernilai ekonomis, juga memiliki nilai estetika. Menurut Kaska, Celebi Toprak, dan Alan (2017), tanaman kucai merupakan tanaman ornamen yang selain untuk kuliner, juga dibudidayakan sebagai tanaman obat tradisional di beberapa negara Asia Timur.

Peran perempuan dalam pengelolaan usahatani Kucai Organik diharapkan memberikan dampak positif dalam peningkatan pendapatan rumah tangga. Meskipun dalam implementasinya di masyarakat masih banyak ditemukan bahwa setiap jenis kegiatan usahatani yang melibatkan wanita tani umumnya hanya dipandang sebagai bentuk partisipasi terhadap kepala keluarga (petani) dan sangat kurang disejajarkan sebagai pengambil keputusan, sehingga besarnya kontribusi terhadap peningkatan pendapatan keluarga hampir tidak pernah diperhitungkan (Rosmini, 2007). Pemanfaatan 
lahan pekarangan tidak terlepas dari pentingnya peran anggota keluarga baik laki-laki maupun perempuan dalam menangkap peluang kerja, meningkatkan pendapatan, dan memberikan nilai tambah bagi kehidupan mereka dalam keluarga maupun dalam bermasyarakat.

Berdasarkan latar belakang tersebut, penelitian ini akan membahas tentang partisipasi perempuan melalui Kelompok Wanita Tani (KWT) dalam pembentukan Kampung Kucai, serta melakukan identifikasi peran gender dalam pengelolaan Usahatani Kucai di lahan pekarangan, dan mengkaji sejauh mana kontribusi perempuan terhadap pendapatan rumah tangga melalui pengoptimalan lahan pekarangan untuk kegiatan usahatani di Kampung Kucai ini. Diharapkan melalui penelitian ini,bias gender dalam masyarakat terutama untuk Ibu Rumah Tangga yang masih mendapatkan stigma negatif terhadap perannya dapat dihapuskan.

\section{METODE PENELITIAN}

Penentuan lokasi penelitian dilakukan secara purposif yaitu di Kampung Kucai, Dusun Kranggan, Desa Pojok, Kabupaten Blitar. Pertimbangan penentuan lokasi penelitian tersebut adalah karena lokasi telah mendapatkan penghargaan juara satu tingkat Kabupaten Blitar sebagai Desa Berseri (Bersih, Sehat dan Lestari) tahun 2017. Penelitian dilaksanakan mulai dari bulan Maret sampai April 2018.

Pengambilan data primer dilakukan dengan Focus Group Discussion (FGD) pada Kelompok Wanita Tani (KWT) yang ada di Dusun Kranggan, yaitu Kelompok Wanita Tani (KWT) Al- Alfiah, An- Nisa, dan Manfaat. Wawancara mendalam dilakukan kepada Kepala Dusun Kranggan, dan kepada pengurus serta anggota Kelompok Wanita Tani (KWT). Observasi partisipatif dilakukan melalui pengamatan secara langsung tentang peran-peran gender dalam optimalisasi lahan pekarangan untuk meningkatkan pendapatan rumah tangga di lokasi penelitian. Sedangkan data sekunder didapatkan dari kantor desa Pojok dan Kantor Sekretariat Kelompok Wanita Tani (KWT). Metode pengambilan sampel yang digunakan dalam penelitian ini yaitu snowball sampling. Jumlah responden dalam penelitian ini sebanyak 20 responden baik suami maupun istri yang terlibat aktif dalam Kelompok Wanita Tani di Kampung Kucai. Selain itu terdapat 5 Key Informan yang penentuannya dilakukan dengan sengaja (purporsive sampling) terdiri dari: tokoh masyarakat, baik formal maupun non-formal, perangkat desa, dan pengurus Kelompok Wanita Tani di Kampung Kucai.

Analisis deskriptif kualitatif digunakan dalam penelitian ini untuk mendeskripsikan partisipasi perempuan tani dalam pembentukan Kampung Kucai dan mendeskripsikan peran perempuan peran gender dalam pengelolaan Usahatani Kucai Organik di lahan pekarangan dengan menggunakan analisis gender model Harvard (Pintakami, 2013). Melalui teknik Analisis gender model Harvard ini peran perempuan tani dapat dilihat dari empat kategori analisis, yaitu profil kegiatan (kegiatan produktif, reproduktif, dan sosial kemasyarakatan), profil akses, profil kontrol, profil manfaat.

Analisis deskriptif kuantitatif digunakan untuk menganalisis kontribusi perempuan terhadap pendapatan rumah tangga melalui pengoptimalan lahan pekarangan untuk kegiatan usahatani di Kampung Kucai. Pendapatan bersih rumah tangga sama dengan pendapatan dari berbagai sumber pendapatan, sektor pertanian, ditambah sektor 
non pertanian jika dalam rumah tangga tersebut suami bekerja di luar sektor pertanian. Sehingga analisis pendapatan atau keuntungan dihitung melalui pengurangan antara penerimaan dengan total pengeluaran rumah tangga selama satu bulan, dengan rumus :

$$
\pi=\mathrm{TR}-\mathrm{TC}
$$

Keterangan :

$$
\begin{array}{ll}
\pi & =\text { pendapatan }(\mathrm{Rp}) \\
\mathrm{TR} & =\text { total penerimaan }(\mathrm{Rp}) \\
\mathrm{TC} & =\text { total biaya }(\mathrm{Rp})
\end{array}
$$

Selanjutnya, untuk mengetahui kontribusi pendapatan perempuan tani terhadap rumah tangga dihitung menggunakan analisis kontribusi. Menurut Yang (dalam Hernanto, 1984), kontribusi pendapatan perempuan terhadap pendapatan rumah tangga dapat dihitung menggunakan rumus sebagai berikut:

Dimana:

$$
\mathrm{K}=\frac{Y w}{Y t} \times 100 \%
$$

$\mathrm{K}=$ Kontribusi pendapatan perempuan tani Kampung Kucai (\%)

$\mathrm{Yw}=$ Beban kerja perempuan tani melakukan peran produktif (jam)

$\mathrm{Yt}=$ Total beban kerja melakukan peran produktif (jam)

\section{HASIL DAN PEMBAHASAN}

\subsection{Partisipasi Wanita Tani Dalam Pembentukan Kampung Kucai Organik}

Partisipasi wanita memiliki peran yang sangat besar dalam pembentukan kampung kucai. Berawal dari pekarangan kosong yang belum dimanfaatkan, salah satu kader melalui Kelompok Wanita Tani mengajak para Ibu rumah tangga di Dusun Kranggan untuk memanfaatkan lahan pekarangan sekitar rumah dengan Usahatani Kucai. Kondisi ini selaras dengan pernyataan Anthopoulo (2010) bahwa partisipasi perempuan terutama pada restrukrisasi daerah pedesaan menegaskan bagaimana perempuan berkontribusi dalam penciptaan mata pencaharian sehingga mendukung kesejahteraan rumah tangga di daerah pedesaan.

Perempuan tani juga berpartisipasi dalam penyiapan sarana produksi pertanian seperti benih dan bibit. Pengadaan benih awalnya didapatkan pada saat studi banding di Batu, Malang. Kemudian secara bergotong- royong para anggota kelompok tani melakukan usaha pembuatan bibit. Bibit- bibit yang sudah berhasil ditanam, dibagikan secara merata kepada seluruh anggota kelompok tani. Setiap anggota tani mendapatkan 10 polibag bibit yang kemudian dari jumlah tersebut dikembangkan menjadi lebih banyak. Bahkan berkat keberhasilan Kelompok Wanita Tani mengembangkan usahatani kucai hingga lokasi tersebut terkenal dengan sebutan Kampung Kucai, pada tahun 2017 kelompok wanita tani baik Al- Alfiah dan An- Nisa mendapatkan bantuan dari lembaga Baitul Maal berupa 1800 bibit. Bantuan bibit tersebut diperuntuhkan untuk anggota kelompok wanita tani yang kurang mampu, dengan kriteria pendapatan bulanan rumah 
tangga $<$ Rp. 1000.000,-. Penerima bantuan bibit hanya ada 20 orang yang diambil masing- masing, 10 anggota kelompok wanita tani Al- Alfiah dan An-Nisa. Kemudian untuk memudahkan pengontrolan terhadap usahatani bibit bantuan 20 anggota penerima membentuk kelompok tani sendiri yang dinamakan kelompok tani Manfaat.

Usaha untuk mempromosikan Kampung Kucai Organik dilakukan melalui ikut serta dalam beberapa lomba, salah satunya lomba Desa Berseri (Bersih, Sehat, dan Lestari) yang diadakan oleh Dinas Lingkungan Hidup (DLH) Kabupaten Blitar tahun 2017. Melalui kompetisi tersebut Kampung Kucai Organik di Dusun Kranggan, Desa Pojok dinobatkan sebagai juara 1. Sebagai upaya peningkatan wawasan untuk pengelolaan Kampung Kucai, para perempuan tani juga melakukan kegiatan studi banding. Antara lain : studi banding di kota Batu, Tulungagung, dan Ngawi dengan materi berupa cara menanam, mengganti media tanam, pembuatan pupuk organik, pemilihan benih yang berkualitas, pembuatan kebun bibit, dan teknik perawatan tanaman. Selain itu, Kelompok Wanita Tani Kampung Kucai juga mendapatkan pembinaan rutin dari Dinas Pertanian, PKK, dan Lemabaga Sosial Pemuda Pancasila Blitar.

\subsection{Identifikasi Peran Gender Dalam Pengelolaan Usahatani Kucai Di Lahan Pekarangan}

Murniati (2004) menyatakan pembagian pekerjaan dalam masyarakat dapat dibagi menjadi tiga kategori pokok yaitu produktif, reproduktif, sosial kemasyarakatan dan dari pekerjaan ini, masyarakat menentukan peran manusianya. Identifikasi peran gender dalam pengelolaan usahatani kucai di lahan pekarangan dapat dianalisis berdasarkan: pembedaan peran/aktifitas antara laki-laki dan perempuan, perbedaan kontrol (kuasa) dan akses (peluang), serta manfaat.

\section{a. Pembedaan Profil Peran/Aktifitas}

Pembedaan peran, kegiatan, atau kerja biasanya berdasarkan kegiatan yang menghasilkan uang, memelihara dan merawat keluarga, pergaulan masyarakat, keagamaan/ritual, pesta, maupun kegiatan politik yang berhubungan dengan pengambilan keputusan (Handayani, 2009; Buvinic dalam Rosmini, 2007). Antara lakilaki dan perempuan umumnya pembedaan peran terdiri dari: 1) kegiatan produktif: adalah kegiatan yang menghasilkan uang atau barang-barang yang bisa dipertukarkan dengan uang; 2) kegiatan reproduktif: adalah kegiatan yang sifatnya merawat keluarga seperti memasak makanan, membersihkan rumah, mengambil air; 3) kegiatan sosial kemasyarakatan: adalah kegiatan-kegiatan masyarakat yang sifatnya menjalin kebersamaan, solidaritas antar warga masyarakat (Puspitawati, 2013; Sudarta 2007).

Kegiatan produktif perempuan tani di Kampung Kucai dibagi menjadi dua yaitu, kegiatan produktif ekonomi (cash) dan non ekonomi (natura). Hal ini sesuai perrnyataan Putri (2007) bahwa beban kerja perempuan secara garis besar dibagi menjadi dua yaitu: beban kerja untuk kegiatan ekonomi (mencari nafkah) dan kegiatan non ekonomi yaitu kegiatan dasar, kegiatan sosial, dan kegiatan rumah tangga. Berikut 
tabel 1 memperlihatkan pembagian kerja produktif ekonomi (cash) antara laki-laki dan perempuan di lahan pekarangan kucai.

Tabel 1. Pembagian Kerja Usahatani Kucai Organik

\begin{tabular}{|l|l|l|c|c|}
\hline No. & \multicolumn{1}{|c|}{ Jenis Kegiatan } & Laki-Laki & Perempuan & $\begin{array}{c}\text { Laki2 dan } \\
\text { Perempuan }\end{array}$ \\
\hline 1. & Pembibitan & & & $\sqrt{ }$ \\
\hline 2. & Penanaman & & $\sqrt{ }$ & \\
\hline 3. & Pupuk & & $\sqrt{ }$ & \\
\hline 4. & Penyiangan & & $\sqrt{ }$ & \\
\hline 5. & Pengendaliah HPT & & $\sqrt{ }$ & \\
\hline 6. & Panen & & $\sqrt{ }$ & \\
\hline 7. & Pasca Panen & & & $\sqrt{ }$ \\
\hline 8. & Pemasaran & & & $\sqrt{ }$ \\
\hline
\end{tabular}

Dari tabel 1 menunjukkan bahwa sebagian besar kegiatan usahatani kucai dilakukan oleh perempuan tani. Kecuali untuk beberapa pekerjaan yang berat dan membutuhkan tenaga laki-laki seperti pembibitan, dalam kegiatan ini laki-laki diperlukan untuk kegiatan contohnya mencangkul tanah, pembangunan bedengan, penyiapan media tanam, pembangunan rumah bibit, dan pembuatan rak bibit. Kemudian pekerjaan lain yang juga melibatkan laki-laki adalah pasca panen dan pemasaran. Pada pasca panen laki-laki ikut serta membantu perempuan tani untuk melakukan sortasi pemilihan kucai yang berkualitas baik untuk dijual dan juga penimbangan berat kucai sebelum di setor kepada kordinator bagian pasca panen di Kelompok Wanita Tani. Begitupun pada kegiatan pemasaran dilakukan secara bersama- sama antara laki-laki dan perempuan setiap harinya. Pada bagian pemasaran, ada delapan orang setiap harinya terdiri dari 3 orang laki-laki dan 5 orang perempuan, yang diambil secara bergantian dari Kelompok Wanita Tani Al- Alfiah, An- Nisa, dan Kelompok Tani Manfaat untuk memasarkan kucai organik ke beberapa pasar di Blitar. Beberapa lokasi yang menjadi tempat pemasaran kucai organik antara lain pasar legi, pasar templek, pasar pon, dan pasar balapan.

Penanaman dilakukan oleh perempuan tani, kegiatan penanaman berupa pemindahan bibit kucai ke polibag atau kaleng bekas sebagai upaya ramah lingkungan pemanfaatan barang bekas. Selain di polibag atau kaleng, ada beberapa perempuan tani yang memiliki pekarangan cukup luas sehingga penanaman kucai dilakukan secara langsung di pekarangan depan rumah. Dalam kegiatan penanaman tidak melibatkan laki-laki dikarenakan penanaman dilakukan dengan pemanfaatan lahan pekarangan sekitar rumah yang luasannya tidak terlalu besar. Penanaman kucai oleh perempuan tani ditunjukkan pada gambar 1. 


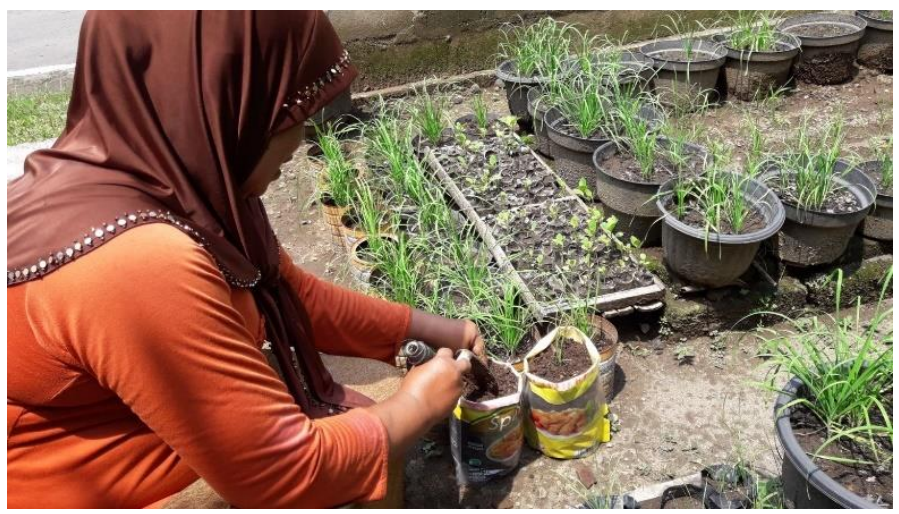

Gambar 1. Penanaman kucai oleh perempuan tani

Kegiatan pemupukan dan penyiangan juga dilakukan oleh perempuan tani. Pemberian pupuk anorganik NPK dilakukan pada saat awal pemindahan bibit ke polibag yang lebih besar, kemudian setelah 15 hari tanam, dan dilanjutkan secara rutin setiap satu bulan sekali ditambahkan dengan pupuk organik atau pupuk kandang. . Sedangkan kegiatan penyiangan dilakukan oleh perempuan tani setiap hari, pada saat pagi atau sore hari seperti ditunjukkan pada gambar 2 .

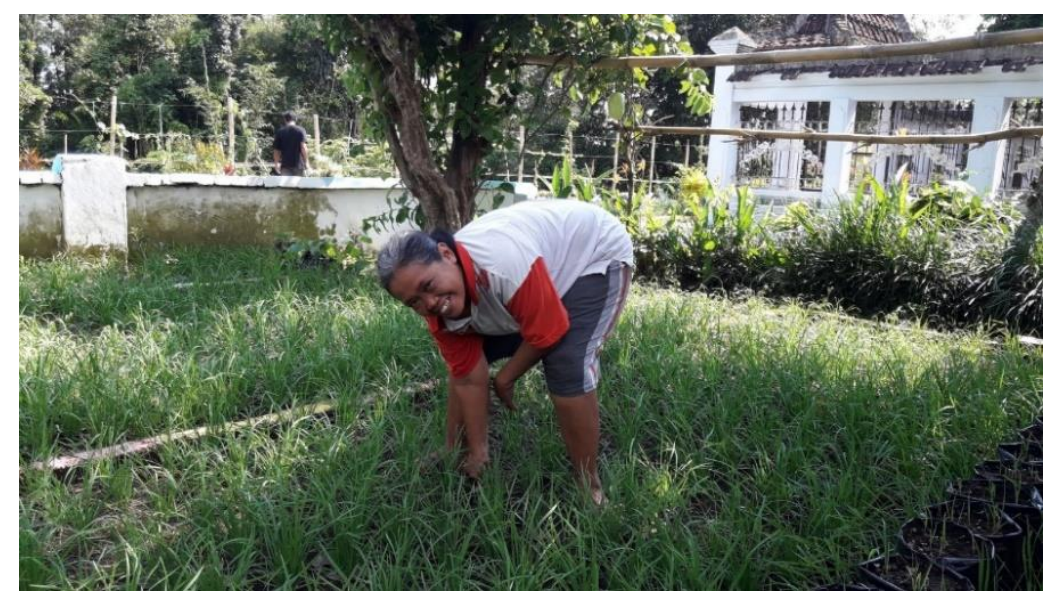

Gambar 2. Penyiangan gulma oleh perempuan tani

Selanjutnya adalah kegiatan panen yang dilakukan sepenuhnya oleh perempuan. Panen setiap harinya dilakukan sebanyak dua atau satu kali, tergantung dari banyaknya permintaan pasar. Panen dilakukan pada pagi hari selepas subuh atau sore hari. Penentuan waktu panen berdasarkan dari permintaan pasar. Panen pada pagi atau sore hari untuk pengiriman di pasar legi, pon, dan balapan.

Aktifitas kegiatan produktif non ekonomi (Natura) adalah aktifitas yang dilakukan oleh laki-laki dan perempuan tani di Dusun Kranggan dalam pemanfaatan keberadaan sumber daya alam secara cuma-cuma. Dalam kegiatan usahatani kucai ini yang termasuk kegiatan non ekonomi (Natura) adalah pemanfaatan sisal hasil panen kucai yang dapat dimanfaatkan untuk konsumsi pribadi sehingga tidak menghilangkan 
nilai ekonomisnya. Pemanfaatan kaleng bekas cat juga merupakan aktifitas produktif non ekonomi (natura). Sebagai bagian dari pemanfaatan limbah, para perempuan tani memanfaatkan sampah kaleng bekas cat untuk pot tanaman kucai. Selain lebih ramah lingkungan, kaleng bekas cat dirasa lebih awet daripada menggunakan polibag.

Dalam menjamin kelangsungan hidup rumah tangga, peran reproduktif merupakan salah satu aktifitas penting untuk mendukung kesejahteraan keluarga. Meskipun secara langsung tidak dapat menghasilkan uang atau barang tetapi keberadaannya tidak bisa tergantikan (Pintakami, 2013). Aktifitas reproduktif di lokasi penelitian secara umum dominan dilakukan oleh perempuan. Hal ini sesuai dengan yang disampaikan oleh Hadiprakoso (2005) mengungkapkan, jika secara biologis perempuan dapat hamil lalu melahirkan sehingga perempuan memiliki peran gender sebagai perawat, pengasuh, dan pendidik anak, sesungguhnya tidak menjadi masalah dan tidak perlu digugat. Namun persoalannya perbedaan peran gender tersebut telah terbentuk dalam kurun waktu yang cukup lama, sehingga terbentuk stereotip "perempuan harus berada di rumah" (Williams, 2018), anggapan bahwa peran perempuan sebagai ibu rumah tangga yang harus mengurus dan merawat anak.

Tabel 2. Aktifitas Gender dalam Kegiatan Reproduktif

\begin{tabular}{|c|c|c|c|c|}
\hline No. & Jenis Kegiatan & $\begin{array}{l}\text { Laki- } \\
\text { Laki }\end{array}$ & Perempuan & $\begin{array}{c}\text { Laki dan } \\
\text { Perempuan }\end{array}$ \\
\hline 1 & $\begin{array}{l}\text { Pengasuhan Anak: } \\
\text { - } \text { Momong anak } \\
\text { - Menyiapkan } \\
\text { keperluan anak } \\
\text { sebelum sekolah } \\
\text { - } \text { Membantu } \\
\text { mengerjakan PR } \\
\text { anak }\end{array}$ & & $\begin{array}{l}\sqrt{ } \\
\sqrt{ }\end{array}$ & \\
\hline 2 & Memasak & & $\sqrt{ }$ & \\
\hline 3 & Membersihkan rumah & & & $\sqrt{ }$ \\
\hline 4 & Berbelanja & & $\sqrt{ }$ & \\
\hline 5 & $\begin{array}{l}\text { Mencuci pakaian dan } \\
\text { alat-alat dapur }\end{array}$ & & & $\sqrt{ }$ \\
\hline
\end{tabular}

Aktifitas sosial kemasyarakatan di Dusun Kranggan bisa dikatakan sebagai kewajiban, terutama kalau aktifitas tersebut menyangkut kepentingan bersama diantara mereka. Seperti aktifitas kerja bakti yang secara kompak seluruh masyarakat baik lakilaki maupun perempuan terlibat untuk membersihkan kampung. Terutama jika lokasi tersebut ditunjuk untuk mewakili Kabupaten untuk menjadi Desa Percontohan. Seluruh masyarakat bergotong royong mempersiapkan segala kebutuhan yang diperlukan. Selengkapnya aktifitas sosial kemasyarakatan laki-laki dan perempuan di Kampung Kucai, Dusun Kranggan, Desa Pojok dapat dilihat pada tabel 3 berikut.

Tabel 3. Aktifitas Gender dalam Kegiatan Sosial Kemasyarakatan 


\begin{tabular}{|c|c|c|c|c|}
\hline No & Jenis Kegiatan & Laki-Laki & Perempuan & $\begin{array}{l}\text { Laki dan } \\
\text { Perempuan }\end{array}$ \\
\hline 1. & $\begin{array}{l}\text { Formal } \\
\text { - PKK } \\
\text { - PNPM } \\
\text { - Bimdu (Bimbingan } \\
\text { Terpadu) } \\
\text { - Posyandu } \\
\text { - Kelompok Tani }\end{array}$ & $\sqrt{ }$ & $\begin{array}{l}\sqrt{ } \\
\sqrt{ }\end{array}$ & $\begin{array}{l}\sqrt{ } \\
\sqrt{ }\end{array}$ \\
\hline 2. & $\begin{array}{l}\text { Non-Formal } \\
\text { - Pengajian } \\
\text { - Arisan } \\
\text { - Kerja Bakti } \\
\text { - Senam } \\
\text { - Tolong menolong/ } \\
\text { sambatan : } \\
\text { (mengawinkan, } \\
\text { mengkhitankan anak, } \\
\text { membantu dalam } \\
\text { kesusahan) }\end{array}$ & & $\begin{array}{l}\sqrt{ } \\
\sqrt{ }\end{array}$ & $\sqrt{ }$ \\
\hline
\end{tabular}

Pada tabel di atas memperlihatkan bahwa laki-laki dan perempuan terlibat secara bersama-sama dalam kegiatan sosial kemasyarakatan baik yang sifatnya formal maupun non formal. Pada kegiatan formal perempuan terlibat dalam PKK, Bimdu (Bimbingan Terpadu), Posyandu, dan Kelompok Tani. Sedangkan untuk program PNPM hanya dilakukan oleh laki-laki saja dikarenakan program tersebut berkaitan dengan bantuan infrastruktur dan membutuhkan tenaga fisik. Hal serupa juga diperlihatkan pada kegiatan non formal dimana perempuan mempunyai kesempatan yang sama dengan laki-laki untuk terlibat dalam kegiatan tersebut.

Pembagian peran produktif, reproduktif, dan sosial kemasyarakatan antara lakilaki dan perempuan dalam pola pembagian waktu nampak pada tabel 4 di bawah ini. Tabel tersebut menunjukkan jadwal harian yang dilakukan oleh laki-laki dan perempuan di Kampung Kucai, baik dalam kegiatan produktif, reproduktif, maupun sosial kemasyarakatan. Dalam tabel tersebut menunjukkan pembagian peran dimana beberapa tugas dilaksanakan oleh laki-laki dan beberapa tugas dilakukan oleh perempuan.

Tabel 4. Jadwal Kegiatan Harian Perempuan Kampung Kucai

\begin{tabular}{|c|l|l|}
\hline No & Jam kerja & Uraian kegiatan \\
\hline 1. & $03.00-05.00$ & $\begin{array}{l}\text { Bangun pagi, beribadah, membersihkan diri,mencuci pakaian, } \\
\text { memasak untuk makan keluarga }\end{array}$ \\
\hline 2. & $05.00-07.00$ & $\begin{array}{l}\text { Panen Kucai yang disetor pada pagi hari, setor ke koordinator } \\
\text { kelompok tani }\end{array}$ \\
\hline 3. & $07.00-08.00$ & $\begin{array}{l}\text { Menyiapkan keperluan anak sekolah, sarapan, mengantarkan } \\
\text { anak ke sekolah }\end{array}$ \\
\hline
\end{tabular}




\begin{tabular}{|c|l|l|}
\hline 4. & $08.00-10.00$ & Melakukan aktifitas di pekarangan \\
\hline 5. & $10.00-13.00$ & Mengikuti kegiatan sosial kemasyarakatan \\
\hline 6. & $13.00-15.00$ & Istirahat di rumah \\
\hline 7. & $15.00-17.00$ & Membersihkan rumah \\
\hline 8. & $17.00-18.00$ & $\begin{array}{l}\text { Panen Kucai yang disetor pada sore hari, setor ke kordinator } \\
\text { kelompok tani }\end{array}$ \\
\hline 9. & $18.00-19.00$ & $\begin{array}{l}\text { Menyiapkan makan malam dan makan malam bersama, } \\
\text { membersihkan peralatan dapur }\end{array}$ \\
\hline 10. & $19.00-21.00$ & Mendampingi anak mengerjakan PR \\
\hline 11. & $21.00-03.00$ & Istirahat, tidur malam \\
\hline
\end{tabular}

Pola alokasi waktu ini memang tidak sama untuk setiap rumahtangga, namun setidaknya terdapat pola yang sama. Pembagian kerja perempuan di bidang pekerjaan produktif juga diikuti dengan keterlibatan laki-laki pada pekerjaan domestik meskipun tidak sebanyak perempuan. Tabel di bawah ini merupakan pembagian jam kerja lakilaki :

Tabel 5. Jadwal Kegiatan Harian Laki- Laki Kampung Kucai

\begin{tabular}{|l|l|l|}
\hline No & Jam kerja & \multicolumn{1}{|c|}{ Uraian kegiatan } \\
\hline 1. & $04.00-05.00$ & Bangun pagi, beribadah, membersihkan diri \\
\hline 2. & $05.00-07.00$ & $\begin{array}{l}\text { Panen Kucai yang disetor pada pagi hari, setor ke koordinator } \\
\text { kelompok tani }\end{array}$ \\
\hline 3. & $07.00-08.00$ & sarapan, membantu mencuci piring/ alat dapur \\
\hline 4. & $08.00-16.00$ & Bekerja di non sektor pertanian (tukang) \\
\hline 5. & $16.00-17.00$ & Istirahat \\
\hline 6. & $17.00-18.00$ & $\begin{array}{l}\text { Panen Kucai yang disetor pada sore hari, setor ke kordinator } \\
\text { kelompok tani }\end{array}$ \\
\hline 7. & $18.00-19.00$ & $\begin{array}{l}\text { Membantu menyiapkan makan malam dan makan malam } \\
\text { bersama }\end{array}$ \\
\hline 8. & $19.00-21.00$ & Mengikuti kegiatan kemasyarakatan \\
\hline 9. & $21.00-04.00$ & Istirahat, tidur malam \\
\hline
\end{tabular}

Berdasarkan tabel 5, dapat diketahui beban kerja antara laki-laki dan perempuan pada tiap pembagian peran. Beban kerja adalah proporsi waktu bekerja (yang dicurahkan untuk kegiatan-kegiatan tertentu di sektor pertanian dan di luar sektor pertanian) terhadap total waktu kerja angkatan kerja. Beban kerja tergantung pada jenis pekerjaan yang dilakukan. Ada jenis-jenis kegiatan yang memerlukan waktu yang banyak dan berkelanjutan, tapi sebaliknya ada pula jenis-jenis kegiatan yang memerlukan waktu kerja yang terbatas ( Nurmanaf, 2006). Pada perempuan beban kerja terbesar pada peran reproduksi yaitu $50 \%$ atau 8 jam/hari. Sedangkan untuk peran produksi dan peran sosial kemasyarakatan masing-masing adalah $31 \%$ dan $19 \%$.Tabel.. menunjukkan bahwa secara umum perempuan mempunyai peran baik sebagai ibu rumah tangga maupun sebagai pencari nafkah, dilakukan dalam kehidupan sehari-hari yang tercermin dalam beban kerja perempuan. 
Tabel 6. Beban Kerja Perempuan

\begin{tabular}{|c|l|c|c|}
\hline \multirow{2}{*}{ No } & \multicolumn{2}{|c|}{ Jam Kerja } & \multicolumn{2}{c|}{ Uraian Kegiatan } \\
\cline { 3 - 4 } & & Jam & Persentase (\%) \\
\hline 1 & Peran produksi & 5 & 31 \\
\hline 2 & Peran reproduksi & 8 & 50 \\
\hline 3 & Peran Sosial kemasyarakatan & 3 & 19 \\
\hline
\end{tabular}

Beban kerja laki-laki ditunjukkan pada tabel 6, dimana beban kerja dominan adalah peran produksi sebesar $71 \%$ atau 10 jam/hari. Peran reproduksi dan sosial kemasyarakatan mempunyai nilai yang sama yaitu $14,5 \%$ atau 2 jam/hari. Nampak bahwa waktu yang dicurahkan oleh laki-laki pada peran reproduksi lebih sedikit dibandingkan perempuan. Hal ini berhubungan dengan pembagian peran perempuan, dimana munculnya anggapan bahwa peran reproduksi adalah tugas perempuan.

Tabel 7. Beban Kerja Laki-Laki

\begin{tabular}{llll}
\multirow{2}{*}{ No } & \multirow{2}{*}{ Jam Kerja } & \multicolumn{2}{l}{ Uraian Kegiatan } \\
\cline { 3 - 4 } & & Jam & Persentase $(\%)$ \\
2 & Peran produksi & 10 & 71 \\
3 & Peran reproduksi & 2 & 14,5 \\
\hline
\end{tabular}

\section{b. Pembedaan Profil Akses dan Kontrol Pada Sumberdaya}

Akses menggambarkan sejauh mana peluang laki-laki dan perempuan di desa penelitian dalam berinteraksi dengan sumber daya yang ada. Yang dimaksud dengan kontrol adalah kemampuan untuk menguasai sumber daya yang ada, sehingga dapat dikatakan seseorang yang memiliki kontrol atas suatu sumber daya memiliki hak untuk menentukan atau mengambil keputusan pada sumber daya tersebut. Fisher (2012) menyatakan keanggotaan perempuan dalam kelompok tani terutama dengan pola pemasaran kolektif berpotensi mengembalikan kendali perempuan yang hilang (meningkatkan akses dan kendali perempuan terhadap penerimaan/keuangan rumah tangga). Kelompok tani semacam ini sangat berpotensi mendukung komersialisasi usaha skala kecil/rumah tangga tanpa ada kesenjangan gender. Tabel 8 berikut memperlihatkan akses dan kontrol pada sumber daya berdasarkan jenis kelamin di Desa Bayem

Tabel 8. Akses dan Kontrol Pada Sumber Daya Berdasarkan Jenis Kelamin

\begin{tabular}{|c|c|c|c|c|}
\hline No & Akses dan Kontrol pada & $\begin{array}{c}\text { Laki- } \\
\text { Laki }\end{array}$ & $\begin{array}{c}\text { Perem- } \\
\text { puan }\end{array}$ & $\begin{array}{c}\text { Laki dan } \\
\text { Perempuan }\end{array}$ \\
\hline 1 & Informasi : & & & $\sqrt{ }$ \\
& $-\quad$ Pertanian & $\sqrt{ }$ & & $\sqrt{ }$ \\
& $-\quad$ Kesar & & & \\
& $-\quad$ Kesehatan & & & \\
\end{tabular}




\begin{tabular}{|c|c|c|c|c|}
\hline 2 & Organisasi & & & $\sqrt{ }$ \\
& $-\quad$ Pemerintahan desa & & $\sqrt{ }$ \\
& - Kelompok Tani & & \\
\hline 3 & Finansial : & & & $\sqrt{ }$ \\
& - Kredit Usaha Tani & & $\sqrt{ }$ \\
\hline 4 & SDA : & & $\sqrt{ }$ \\
& $-\quad$ Lahan pekarangan & & & \\
& & & & \\
\hline
\end{tabular}

Pada tabel di atas, memperlihatkan bahwa akses dan kontrol laki-laki dan perempuan terhadap informasi pertanian dan kesehatan sama. Sedangkan informasi pasar hanya dimiliki oleh laki-laki dikarenakan pekerjaan ini membutuhkan tenaga dan waktu yang lebih besar untuk melakukan survei pasar untuk komoditi kucai. Pada akses dan kontrol laki-laki dan perempuan untuk organisasi juga seimbang, yang berbeda hanya pada kegiatan PKK yang diperuntukan khusus untuk perempuan karna melibatkan pendekatan terhadap masyarakat dan anak- anak.

Akses dan kontrol terhadap finansial Kredit Usaha Tani dapat dilakukan baik oleh laki-laki maupun perempuan berupa simpan pinjam di Kelompok Tani atau Kelompok Wanita Tani. Kemudian untuk sumber daya alam, semua bisa mendapatkan akses dan kontrolyang sama baik terlibat dalam pemanfaatan pekarangan dan pengadaan sumber air. Seperti gambar yang menunjukkan ketersediaan sumber air sumur untuk mengairi lahan percontohan usahatani kucai milik Kelompok Wanita Tani di Desa Kucai.

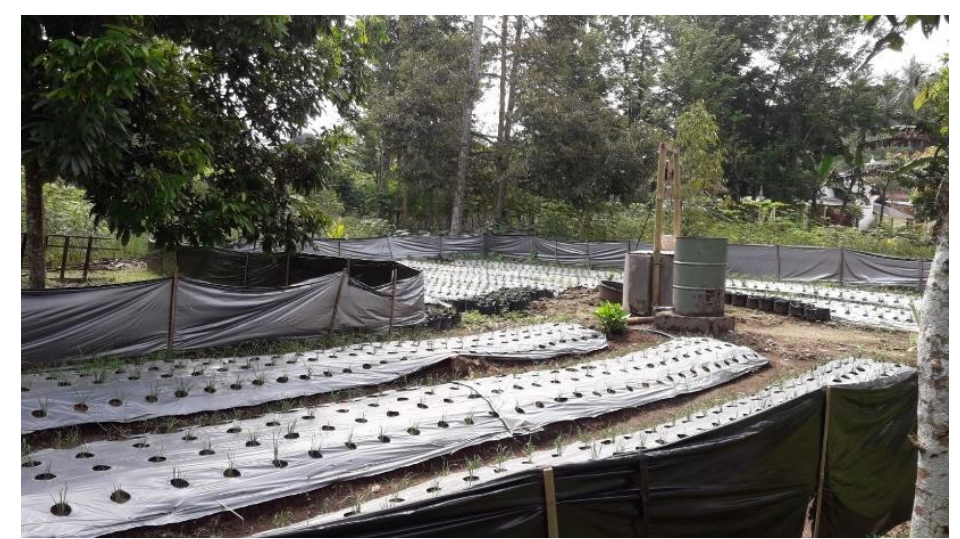

Gambar 3. Lahan percontohan usahatani Kampung Kucai beserta sumber air

\section{c. Pembedaan Profil Manfaat}

Aspek manfaat merupakan kesempatan untuk memperoleh manfaat atau hasil dari pembagian kerja berdasarkan jenis kelamin. Aspek manfaat berupa kesempatan untuk memperoleh manfaat meliputi pengalaman dan ketrampilan.

Tabel 9. Manfaat Berdasarkan Jenis Kelamin 


\begin{tabular}{|c|l|c|c|c|}
\hline No & Manfaat berupa & $\begin{array}{c}\text { Laki- } \\
\text { Laki }\end{array}$ & $\begin{array}{c}\text { Perem- } \\
\text { puan }\end{array}$ & $\begin{array}{c}\text { Laki dan } \\
\text { Perempuan }\end{array}$ \\
\hline 1 & Pengalaman & & & $\sqrt{ }$ \\
\hline 2 & Ketrampilan & & $\sqrt{ }$ & \\
\hline
\end{tabular}

Berdasarkan tabel 9, manfaat berupa pengalaman dirasakan bersama oleh lakilaki dan perempuan. Hal ini dikarenakan antara laki-laki dan perempuan mempunyai kesempatan yang sama untuk terlibat dalam kelompok tani. Pengalaman juga didapatkan dari kegiatan usahatani Kucai melalui kelembagaan penunjang agribisnis. Kelembagaan ini berfungsi mendukung dan melayani serta mengembangkan kegiatan usahatani kucai. Jasa penunjang dalam Kampung Kucai meliputi: Kelembagaan Kelompok Wanita Tani baik Al- Alfiah, An- Nisa, dan Manfaat, Dinas Pertanian, Baitul Maal, Gerakan Pemuda Pancasila.

Sedangkan untuk manfaat berupa ketrampilan dirasakan oleh perempuan. Dikarenakan sejak pembentukan Kampung Kucai di Dusun Kranggan, Desa Pojok, Kabupaten Blitar, akhirnya pemerintah daerah memberikan perhatian lebih terhadap lokasi penelitian dan selalu diikut sertakan dalam kompetisi lokal maupun nasional. Sejak saat itulah, pembinaan selalu diberikan melalui Kelompok Wanita Tani untuk mampu mengembangkan potensi yang dimiliki Kampung Kucai. Manfaat ketrampilan meliputi ketrampilan bercocok tanam dan daur ulang sampah anorganik. Kegiatan daur ulang melibatkan ketrampilan perempuan tani dalam menciptakan produk yang lebih bermanfaat tampak pada gambar.

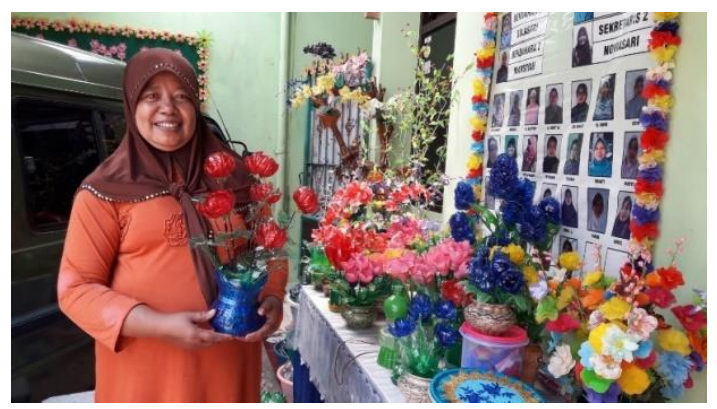

Gambar 4. Ketrampilan daur ulang sampah anorganik

\subsection{Kontribusi Perempuan Terhadap Pendapatan Rumah Tangga di Kampung Kucai}

Alston (2011) menyatakan bahwa Kontribusi ekonomi perempuan adalah melalui keterlibatan dalam pertanian, pemasukan di luar sektor pertanian, kegiatankegiatan sosial, dan peranannya yang sangat luas pada pekerjaan mengurus rumah tangga. Pada lokasi penelitian sumber penerimaan rumah tangga perempuan tani kucai terdiri dari dua jenis yaitu, penerimaan yang didapatkan dari usahatani kucai dan penerimaan suami yang bekerja di sektor non pertanian. Secara umum pekerjaan suami dari para perempuan tani kucai adalah buruh kasar seperti : kuli bangunan, tukang kayu, 
Lintar Brillian Pintakami. 2017. Analisis Kontribusi Gender Dalam Budidaya Tanaman Kucai

Skala Rumah Tangga Di Lahan Pekarangan

Journal Viabel Pertanian. (2018), 12(1) 27-48

atau tukang bubut. Pada tabel 10 memperlihatkan rincian dari penerimaan, pengeluaran, dan pendapatan rumah tangga perempuan tani di Kampung kucai selama satu bulan.

Tabel 10. Uraian Perhitungan Pendapatan Rumah Tangga

\begin{tabular}{|c|c|c|c|}
\hline No & Uraian & Unit & $\begin{array}{l}\text { Rata- } \\
\text { Rata/Bulan } \\
\text { (Rupiah) }\end{array}$ \\
\hline \multicolumn{4}{|c|}{ Penerimaan Rumah Tangga } \\
\hline \multirow[t]{2}{*}{1} & Sektor Pertanian & & \\
\hline & $\begin{array}{l}\text { Produksi Kucai @ } \\
\text { Rp.6.000,- }\end{array}$ & $50 \mathrm{~kg}$ & 300.000 \\
\hline \multirow[t]{2}{*}{2} & Non Pertanian & & \\
\hline & $\begin{array}{l}\text { Buruh kasar @ Rp. } \\
65.000,-\end{array}$ & $25 \mathrm{HOK}$ & 1.625 .000 \\
\hline \multicolumn{3}{|c|}{ Total Revenew } & 1.952 .500 \\
\hline \multicolumn{4}{|c|}{ Pengeluaran } \\
\hline 1 & Sektor Pertanian & & \\
\hline a. & Polibag & 1 pak & 10.000 \\
\hline b. & $\begin{array}{l}\text { Pupuk Anorganik } \\
\text { (NPK) }\end{array}$ & $1 / 2 \mathrm{~kg}$ & 8.000 \\
\hline c. & Pupuk Kandang & $25 \mathrm{~kg}$ & 5.000 \\
\hline d. & Obat Kocor & $5 \mathrm{~kg}$ & 10.000 \\
\hline e. & Biaya lain-lain & & 25.000 \\
\hline \multicolumn{3}{|c|}{ Total } & 58.000 \\
\hline 2 & $\begin{array}{l}\text { Pengeluaran } \\
\text { rumah tangga }\end{array}$ & & \\
\hline a. & $\begin{array}{l}\text { Beras (10 } \\
\text { Kg/bulan) }\end{array}$ & 1 bulan & 100.000 \\
\hline b. & $\begin{array}{l}\text { Belanja (Lauk- } \\
\text { Pauk) }\end{array}$ & 30 hari & 600.000 \\
\hline c. & $\begin{array}{l}\text { Keperluan sekolah } \\
\text { anak }\end{array}$ & 1 bulan & 250.000 \\
\hline d. & Listrik & 30 hari & 100.000 \\
\hline e. & Komunikasi & 1 bulan & 50.000 \\
\hline f. & Gas & 1 tabung & 18.000 \\
\hline \multicolumn{3}{|c|}{ Total } & 1.118 .000 \\
\hline 3 & $\begin{array}{l}\text { Pengeluaran } \\
\text { Sosial } \\
\text { kemasyarakatan }\end{array}$ & & \\
\hline a. & Iuran pembinaan & $1 \mathrm{KK}$ & 20.000 \\
\hline b. & $\begin{array}{l}\text { Iuran Anggota } \\
\text { kelompok }\end{array}$ & 2 orang & 4.000 \\
\hline
\end{tabular}




\begin{tabular}{|c|c|c|}
\hline & $\begin{array}{l}\text { Keperluan sosial } \\
\text { c. }\end{array}$ & 35.000 \\
\hline \multicolumn{2}{|c|}{ Total } & $\mathbf{5 9 . 0 0 0}$ \\
\hline Total Cost & $\mathbf{1 . 2 3 5 . 0 0 0}$ \\
\hline $\begin{array}{c}\text { Pendapatan Bersih Rumah Tangga } \\
(\boldsymbol{\pi}=\text { TR- TC })\end{array}$ & $\mathbf{6 9 0 . 0 0 0}$ \\
\hline
\end{tabular}

Total penerimaan rumah tangga perempuan tani selama satu bulan sebesar Rp. 1.952.500,-, yang mana didapatkan dari penerimaan sektor pertanian usahatani kucai dan sektor non pertanian. Hal tesebut sesuai dengan pernyataan dari Yuliati (2015) bahwa penerimaan rumahtangga di pedesaan berasal lebih dari satu sumber penerimaan yaitu berasal dari sektor pertanian maupun dari luar sektor pertanian. Besarnya penerimaan masing- masing baik dari usahatani kucai maupun sektor non pertanian adalah Rp. 300.000,- dan Rp. 1.625.000,-. Sedangkan untuk pengeluaran terdiri dari pengeluaran sektor pertanian, rumah tangga, dan sosial kemasyarakatan. Pengeluaran sektor pertanian merupakan biaya produksi yang dikeluarkan dalam usahatani kucai, pengeluaran rumah tangga perempuan tani diasumsikan terdiri dari 4 jiwa/KK sesuai dengan rata-rata jumlah anggota keluarga di lokasi penelitian. Pengeluaran sosial kemasyarakatan meliputi seluruh kegiatan sosial yang ada di Kampung Kucai mulai dari iuran pembinaan, iuran anggota kelompok, dan sosial kemasyarakatan lainnya seperti kerja bakti, bowo, slametan, dan sebagainya. Total pengeluaran rumah tangga perempuan tani adalah sebesar Rp. 1.235.000,-/bulan.

Pendapatan bersih dari rumah tangga dihitung berdasarkan penerimaan yang didapatkan setiap bulannya dikurangi dengan seluruh pengeluran yang ditanggung oleh rumah tangga tersebut. Jumlah pendapatan bersih yang didapatkan oleh rumah tangga perempuan tani kucai di Dusun Kranggan, Desa Pojok, Kabupaten Blitar sebesar Rp. 690.000,-/bulan. Pendapatan inilah yang nantinya akan dijadikan sebagai tabungan atau simpanan untuk keperluan mendadak di masa depan oleh rumah tangga perempuan tani di Kampung Kucai.

Jika dihitung berapa kontribusi perempuan tani terhadap pendapatan bersih rumah tangga, dapat diperoleh melalui beban kerja atau waktu yang dialokasikan perempuan tani untuk melakukan peran produktif dibagi total beban kerja peran produktif laki-laki dan perempuan kemudian dikalikan total pendapatan rumah tangga. Pada tabel dibawah ini merupakan kontribusi perempuan tani terhadap pendapatan rumah tangga selama satu bulan. 
Tabel 11. Kontribusi Terhadap Pendapatan Rumah Tangga

\begin{tabular}{|c|c|c|c|c|}
\hline \multirow{2}{*}{ No } & \multirow{2}{*}{ Uraian } & \multicolumn{2}{|c|}{$\begin{array}{l}\text { Alokasi Peran } \\
\text { Produksi }\end{array}$} & \multirow{2}{*}{$\begin{array}{c}\text { Kontribusi } \\
\text { Terhadap } \\
\text { Pendapatan } \\
\text { (Rp/bulan) }\end{array}$} \\
\hline & & Jam & $\begin{array}{c}\text { Persentase } \\
(\%)\end{array}$ & \\
\hline 1. & Perempuan & 5 & 33.3 & 229.770 \\
\hline 2. & Laki-laki & 10 & 66.7 & 460.230 \\
\hline
\end{tabular}

Pada tabel di atas, menunjukkan bahwa alokasi waktu laki- laki pada peran produksi lebih besar daripada perempuan. Laki- laki mengalokasikan peran produksi selama $10 \mathrm{jam} / \mathrm{hari}$ atau $66,7 \%$. Sedangkan perempuan mengalokasikan peran produksi selama $5 \mathrm{jam} /$ hari atau 33,3\%. Sehingga kontribusi masing- masing dalam pendapatan bersih rumah tangga setiap bulan adalah Rp. 460.230,- untuk laki-laki dan Rp. 229.770,untuk perempuan. . Hal tersebut sesuai dengan pendapat Ilyan (2014), kontribusi wanita dalam proses produksi (ekonomi) yang telah mampu meningkatkan kesejahteraan keluarga, lebih-lebih bagi keluarga yang mampu, sedangkan bagi wanita dan rumah tangga yang belum mampu, kontribusinya secara nyata memberikan sumbangan untuk kelangsungan rumah tangganya.

Secara umum,peran laki- laki dalam kegiatan produksi lebih besar dua kali lipat dari perempuan tani, meskipun demikian, perempuan tani mampu mengalokasikan waktunya lebih besar untuk tetap melakukan peran reproduksinya dalam rumah tangga antara lain mengurus anak, memasak, menyiapkan makanan, mencuci piring, dan membersihkan rumah. Sedangkan petani laki-laki sedikit mengalokasikan waktunya untuk peran reproduksi. Selain itu perempuan tani mampu menyeimbangkan waktu untuk tetap terlibat secara aktif dalam sosial kemasyarakatan lebih besar sedikit dibandingkan laki-laki (Tabel 6).

\section{KESIMPULAN}

Perempuan memainkan peran penting dalam merintis Kampung Kucai. perempuan melalui Kelompok Wanita Petani menginspirasi ibu rumah tangga Kranggan Hamlet untuk memanfaatkan halaman rumah mereka untuk pertanian lokio. Petani perempuan juga berpartisipasi dalam persiapan input pertanian seperti benih dan bibit. Sebagai upaya untuk meningkatkan kesadaran terhadap pengelolaan berkelanjutan Kampung Kucai, studi kunjungan dilakukan oleh petani perempuan. Beban kerja wanita lebih besar pada peran reproduksi, yang mencapai 50\% atau 8 jam sehari, sementara peran produktif dan sosial mereka masing-masing $31 \%$ dan $19 \%$. Beban kerja pria didominasi dalam peran produktif yang terhitung $71 \%$ atau 10 jam per hari. Pria berbagi nilai yang sama untuk peran reproduktif dan sosial yang menyumbang $14,5 \%$ atau 2 jam per hari. Ditemukan bahwa pria mendedikasikan waktu yang jauh lebih rendah untuk peran produktif dibandingkan dengan rekan-rekan wanita mereka. Pria dan wanita berbagi manfaat yang berpengalaman, karena akses yang sama ke kelompok petani tercapai. Manfaat keterampilan dirasakan oleh wanita. Manfaat keterampilan termasuk kemampuan menanam dan daur ulang sampah anorganik. Petani wanita telah mengembangkan keahlian dalam menggunakan kembali botol dan kantong plastik daur 
ulang untuk menciptakan produk yang bermanfaat. Rata-rata pendapatan rumah tangga petani perempuan bulanan adalah Rp. 1.925.000, -, yang bersumber dari pertanian lokio dan pekerjaan non-pertanian digabungkan. Laki-laki mengalokasikan peran yang lebih produktif daripada rekan-rekan perempuan mereka dengan kesenjangan jam kerja 5 atau $33,3 \%$, sehingga dihargai keuntungan moneter yang lebih tinggi. Umumnya pria terhitung dua kali lebih banyak dalam pekerjaan produktif dibandingkan dengan wanita. Namun, perempuan

Mampu mendedikasikan waktu dan upaya yang signifikan untuk melakukan peran reproduktif mereka sambil mempertahankan peran produktif mereka dibandingkan dengan rekan-rekan pria mereka. Selain itu, petani perempuan mampu menjaga keseimbangan waktu untuk tetap aktif terlibat dalam pekerjaan sosial dalam waktu yang lebih sedikit daripada laki-laki.

\section{DAFTAR PUSTAKA}

Alston, M., 2011. Gender and climate change in Australia. Journal of Sociology, 47(1), pp.53-70.

Anthopoulou, T., 2010. Rural women in local agrofood production: Between entrepreneurial initiatives and family strategies. A case study in Greece. Journal of Rural Studies, 26(4), pp.394-403.

Ashari, S. T., 2012. Potensi dan Prospek Pemanfaatan Lahan Pekarangan Untuk Mendukung Ketahanan Pangan. Jakarta : Pusat Sosial Ekonomi dan Kebijakan Pertanian Press.

BPS, 2017. Statistik Indonesia 2017. Jakarta: Badan Pusat Statistik Republik Indonesia.

Fischer, E.and Qaim, M., 2012. Gender, Agricultural Commercialization, and Collective Action in Kenya. Food Security, 4 (3), pp.441- 453.

Hadiprakoso, A., 2005. Penguatan peran gender dalam pemberdayaan ekonomi keluarga miskin: Studi kasus kelompok Dasa Wisma Desa Sudagaran [tesis]. Bogor (ID): Institut Pertanian Bogor.

Handayani, 2009. Kontribusi Pendapatan Ibu Rumah Tangga Pembuat Makanan Olahan Terhadap Total Pendapatan Keluarga. Jurnal Kependudukan dan Pengembangan Sumber Daya Manusia, Volume V , 63.

Hernanto, F., 1984. Aspek- Aspek Pendapatan Ekonomi. Jakarta : Badan Penelitian Dan Pengembangan Pertanian.

Kaska, A., Celebi Toprak, F. and Alan, A.R., 2017. Morphological and Cytological Characterization of Gynogenic Garlic Chive (Allium tuberosum Rottler ex Spreng) Lines.

Murniati, N., 2004. Getar Gender/Perempuan Indonesia dalam Perspektif Sosial, Politik, Ekonomi, Hukumdan Ham. Magelang: Indonesiatera. 
Ningtyas, B.R.., 2013. Dampak Pembangunan Sektor Pertanian Terhadap Perekonomian Jawa Timur: Studi Kasus Penerapan Model Input Output. Surabaya: Media Press.

NURMANAF, A.R., 2006. Peranan Sektor Luar Pertanian terhadap Kesempatan Kerja dan Pendapatan di Pedesaan Berbasis Lahan Kering. SOCA: Socioeconomics of Agriculture and Agribusiness, 6(3).

Pintakami, L.B., Yuliati, Y. and Purnomo, M., 2013. Keterlibatan Perempuan Tani Pada Program Pengelolaan Hutan Bersama Masyarakat (PHBM) Dalam Rangka Mencapai Kesejahteraan Rumah Tangga (Studi Kasus Di Desa Bayem, Kecamatan Kasembon, Kabupaten Malang). Indonesian Journal of Women's Studies, 1(1).

Puspitasari, N., Puspitawati, H. dan Herawati, T., 2013. Peran Gender, Kontribusi Ekonomi Perempuan, dan Kesejahteraan Keluarga Petani Hortikultura. Jurnal Ilmu Keluarga \& Konsumen, 6(1), pp.10-19.

Rahayu, M., 2005. Keanekaragaman Tanamanan Pekarangan dan Pemanfaatannya di Desa Lampeapi, Pulau Wawoni, Sulawesi Selatan. Jakarta : Bidang Botani, Pusat Penelitian Biologi.

Rosmini, 2007. Keterlibatan Wanita Tani Pada Kegiatan Usahatani "Bawang Goreng Lokal Palu” Dalam Upaya Peningkatan Pendapatan Keluarga Di Kabupaten Donggala. Agroland 14 (3) : $201-207$.

Susilowati, S.H. and Maulana, M., 2016. Luas Lahan Usaha Tani dan Kesejateraan Petani: Eksistensi Petani Gurem dan Urgensi Kebijakan Reforma Agraria. Jakarta: Analisis Kebijakan Pertanian, 10(1), pp.17-30.

Williams, W.W., 2018. The equality crisis: Some reflections on culture, courts, and feminism [1982]. In Feminist legal theory (pp. 13-34). Routledge.

Yuliati, Yayuk. dan Bhastoni1, Khamiliya, 2015. Peran Wanita Tani Di Atas Usia Produktif Dalam Usahatani Sayuran Organik Terhadap Pendapatan Rumah Tangga Di Desa Sumberejo Kecamatan Batu. Jurnal Habitat, Volume 26, No. 2, Agustus 2015, Hal. 119-129.

Yulida, R., 2013. Kontribusi Usahatani Lahan Pekarangan terhadap Ekonomi Rumah Tangga Petani di Kecamatan Kerinci Kabupaten Pelalawan. IJAE (Jurnal Ilmu Ekonomi Pertanian Indonesia), 3(2), pp.135-154. 